\title{
LEAKAGE OF VOLATILE ANAESTHETICS FROM AGENT-SPECIFIC KEYED VAPOURIZER FILLING DEVICES
}

\author{
J.M. Davies, L. Strunin and D.B. Craig
}

\begin{abstract}
Agent-specific keyed vapourizer filling devices were designed to ensure that an anaesthetic vapourizer is filled with the correct agent. Since there appear to be no reports of possible loss of volatile agent or operating room pollution resulting from either the design or patterns of use of these devices, measurements were made with three anaesthetic agents and two methods of use. First, two bottles each of methoxyflurane, enflurane and halothane were fitted with a suitable filling device and the weight of agent lost from each bottle over six weeks was measured. Bottle \#1 of each agent remained without agitation between weighings; bottle \#2 was tipped to mimic filling of a vapourizer. Weight loss over the six week period was 2.76 and 3.15 per cent of the halothane, 2.22 and 2.43 per cent of the enflurane, and 0.58 and 0.96 per cent of the methoxyflurane, for bottles \# 1 and \#2, respectively. Second, pollution was measured with an infra-red analyser for halothane, using bottles \# 1 and \#2, as described above, and a third bottle on which the filling device was replaced by the screw-on cap after each filling of the vapourizer. Vapour loss was undetectable for bottle \#1, between 25 and $30 \mathrm{ppm}$ for bottle \#2, and between 350 and $400 \mathrm{ppm}$ for bottle \#3. Thus, although the design of the filling devices results in loss of the anaesthetic agent, this loss represents potential pollution only when the device is replaced by the screw-on cap between use. Therefore, when using filling devices, these should be left on the bottle of volatile agent between fillings to decrease operating room pollution.
\end{abstract}

Key Words: Equipment, vapourizer filling devices; Operating Rooms, air pollution.

AGENT-SPECIFIC keyed vapourizer filling devices were recognized by the Canadian Standards Association ${ }^{1}$ in 1975 and were designed to ensure that "a vapourizer of an anaesthetic machine is filled only with the intended liquid anaesthetic". ' Use of these devices requires that the anaesthetist open the bottle of volatile anaesthetic, replacing the screw-on cap with the keyed filler port. The vapouriser may now be filled and then the bottle with filling device removed from the vapourizer coupling. However, at this point there are different patterns of use, which we have observed in two Canadian university anaesthetic departments. In Centre A, after detaching the bottle from the vapourizer, the anaesthetist immediately replaces the keyed filling device with the screw-on cap, hanging the device from the back bar of the anaesthetic machine and return-

J.M. Davies, M.D., F.R.C.P.(C), Assistant Professor; L. Strunin, M.D., F.F.A.R.C.S., F.R.C.P.(C), Professor \& Head; Department of Anaesthesia, Foothills Hospital and Health Sciences Centre, University of Calgary, Calgary, Alberta, T2N 2T9. D.B. Craig, M.D., F.R.C.P.(C), Professor; Department of Anesthesia, Health Sciences Centre, University of Manitoba, Winnipeg, Manitoba, R3E 0Z3. ing the bottle to the drug cart. This is done 'so as to prevent constant loss of the agent by vapourisation through the holes of the filling device'. In Centre $\mathrm{B}$, after returning the bottle to the anaesthetic cart, the filling device is left on, and not replaced by the cap. This is done because 'there is negligible loss of the agent through the holes of the filler port'. In both centres the method of use is a result of consideration of the economics pertaining to the use of filling devices.

In neither centre, however, is there consideration of potential operating room pollution in relation to the pattern of use of the filling devices. We therefore studied the loss of three commonly used volatile anaesthetics from bottles fitted with keyed filling devices and examined the effect on operating room pollution with the two different patterns of use of these devices.

\section{Materials and Methods}

This experiment was in two parts. First, the percentage of each agent lost daily through the filling devices was examined by calculating the

Can. Anaesth. Soc. J., vol. 29, no. 5, September 1982 
TABLE I

\begin{tabular}{lccc}
\hline \hline & \multicolumn{2}{c}{$\begin{array}{c}\text { Weight loss as per cent of } \\
\text { Initial Weight }\end{array}$} & \\
\cline { 2 - 3 } Agent & Bottle \#1 & Bottle \#2 & $\begin{array}{r}\text { Vapour Pressure } \\
\text { (mm Hg at 20 } 0^{\circ} \mathrm{C} \text { ) }\end{array}$ \\
\hline methoxyflurane & $\mathbf{0 . 5 8 \%}$ & $0.96 \%$ & 22.5 \\
enflurane & $2.22 \%$ & $2.43 \%$ & 175.0 \\
halothane & $2.76 \%$ & $3.15 \%$ & 241.0 \\
\hline
\end{tabular}

Weight loss of the three volatile anaesthetic agents (as per cent of initial weight) measured over a six week period. Bottle \# I remained on the laboratory bench without agitation. Bottle \#2 was tipped to mimic filling of the vapourizer and then retumed to the laboratory bench.

weight loss of each agent. Two bottles each of methoxyflurane, enflurane and halothane were weighed with the screw-on cap in place. A suitable filling device for each bottle was then weighed, and the screw-on cap replaced by the device. Each bottle (with device) was then re-weighed, as was each screw-on cap. The bottles were maintained on a vibration-free bench, in a well-ventilated laboratory, where mean ambient temperature was $21^{\circ} \mathrm{C}$. Measurements were made over a six week period, initially daily, then every other day, and then at irregular intervals.

The two bottles of each agent were labelled \#1 and \#2. Bottle \#1 was simply weighed and then returned, without agitation, to the laboratory bench. Bottle \#2 was weighed and then tipped, to mimic filling of the vapouriser, and then weighed again. The amount of agent tipped out (into a collection bottle) was also calculated. At the end of the experiment, the residual volatile agent in each bottle was poured off, and the bottle thoroughly dried and then weighed, in order to calculate initial volatile agent weight. These measurements are shown in Table 1 .

In the second part of the experiment, operating room pollution with the two different patterns of use of the filling devices was examined. To measure trace concentrations of the volatile anaesthetic (halothane only), a calibrated (parts per million) long-cell infra-red analyzer (Miran IA, Foxboro, Canada, Ltd.) was used. The sampling port of the analyzer was kept at $30 \mathrm{~cm}$ from the holes of the filling device. Three bottles of halothane were each fitted with a keyed filling device. Bottles \# 1 and \#2 were as described above (\#1 left without agitation and \#2 tipped to mimic filling of the vapourizer as in Centre $B$ ). Bottle \#3 was as described for the method of use in Centre A (after filling the vapourizer, the
TABLE II

\begin{tabular}{lccc}
\hline \hline & \multicolumn{3}{c}{ Vapour Loss (ppm) } \\
\cline { 2 - 4 } Agent & Bottle \#1 & Bottle \#2 & Bottle \#3 \\
\hline halothane & 0 & $25-30$ & $350-400$ \\
\hline
\end{tabular}

Vapour loss of halothane as measured in parts per million (ppm) by infra-red analysis. Bottle \# 1 remained on the laboratory bench without agitation. Bottle \#2 was tipped to mimic filling of the vapourizer and then retumed to the laboratory bench with the filling device left on. Bottle \#3 was tipped to mimic filling of the vapourizer and the the filler port removed and the screw-cap replaced.

keyed device replaced by the bottle's screw-on cap). These results are shown in Table II.

\section{RESULTS}

The results shown in Table I represent the percent weight loss (of initial weight) of the three volatile anaesthetic agents, from bottles fitted with keyed filling devices. As shown for Bottle \#1 (left without agitation), over the six week period of measurement, there was loss of each of the three volatile anaesthetics: 2.76 per cent of halothane, 2.22 per cent of enflurane and 0.58 per cent of methoxyflurane. Also, the loss was greatest for each of the three agents from Bottle \#2 (tipped to mimic filling of the vapourizer), with 3.15 per cent of halothane, 2.43 per cent of enflurane and 0.96 per cent of methoxyflurane. The values for vapour pressure for each of the three agents as measured at $20^{\circ} \mathrm{C}^{2}$ are also shown.

The results shown in Table II represent the vapour loss of halothane as measured in parts per million (ppm) by infra-red analysis. The greatest 'pollution' (between $350 \& 400$ ppm) was seen 
with Bottle \# 3, when the keyed device was used as in Centre A (after tipping the bottle to mimic filling of the vapourizer, the keyed device was replaced with the screw-on cap). Vapour loss of greater than 25 and less than $30 \mathrm{ppm}$ was seen with Bottle \#2, when the keyed device was used as in Centre B (keyed device left on the bottle after filling the vapourizer). No detectable vapour loss (at $30 \mathrm{~cm}$ from the analyzer inlet port) was seen with Bottle \# 1 (left undisturbed on the laboratory bench).

\section{Discussion}

Use of agent-specific keyed filling devices for volatile anaesthetic vapourizers has improved operating room safety for the patient: no reports can be found in the anaesthetic literature of misfilled vapourizers since their introduction. It is possible, of course, to defeat the design of the filling devices by either inverting the keyed collar on the bottle ${ }^{3}$ or by simply transferring liquid anaesthetic agent into the 'wrong' bottle. In addition, filling devices have improved the safety of operating rooms for theatre personnel; by virtue of their 'closed' design, these keyed ports decrease the anaesthetic gas pollution of operating rooms during filling of vapourizers. ${ }^{4}$ However our results indicate that there is constant loss of volatile anaesthetics through the holes of keyed filling devices and this loss is proportional to the vapour pressure of the agent. Furthermore, the pattern of use of the filling device might contribute to further loss of the volatile agents. As shown above, the pattern of use as practised in Centre $A$ is the more polluting of the two. Close observation of the keyed device, upon its immediate separation from the bottle after filling a vapourizer, reveals a trickle of liquid anaesthetic onto the anaesthetic cart or machine. Using halothane, reproduction of this pattern of use showed concentrations of greater than $350 \mathrm{ppm}$ as measured with the infra-red analyzer. This represents potential pollution far in excess of that deemed acceptable by the National Institute for Occupational Safety and Health (NIOSH), who recommended that a timeweighted average of $2 \mathrm{ppm}$ of halothane should not be exceeded in the atmosphere of operating rooms. ${ }^{5}$

Only halothane was used in the second part of the study as it remains, in many centres, (for example, those with high paediatric populations), the most commonly used agent. The results for the other two agents would be expected to be of similar pattern, but with absolute results proportional to their vapour pressure.

In summary, we would recommend that, when using keyed filling devices, these be left on the bottle of volatile anaesthetic in order to decrease operating room pollution.

\section{REFERENCES}

1. CSA Standard ZI68.4 - 1975. Keyed filling devices applied to anaesthetic equipment. Canadian Standards Association, Rexdale, Ontario (1975).

2. Gray, T.C., NunN, J.F., \& UTting, J.E. General Anaesthesia, 4th ed. London: Butterworths (1979).

3. MAR, J. A dangerous error in Fluothane packaging. CMA Journal 122: 990 (1980).

4. O'Carroll, T.M., Greenbaum, R. \& ThornTON, P.G.N. Agent-specific filling devices: an evaluation of two prototypes. Anaesthesia 35: 807 (1980).

5. National Institute for Occupational Safety and health. Criteria for a recommended standard: Occupational exposure to waste anesthetic gases and vapors. DHEW Publication No. (NIOSH) 77-140. Cincinnati, Ohio (1977).

\section{RÉSUMÉ}

Les vaporisateurs à calibration spécifique nécessitent l'utilisation d'un dispositif de remplissage special qui se fixe au goulot du flacon contenant l'agent volatil et permet ainsi d'éviter les erreurs d'identification. Lorsqu'il est laissé en permanence sur le flacon, ce dispositif pourrait permettre une fuite de l'agent et ainsi causer de la pollution; c'est ce que les auteurs ont voulu étudier en utilisant trois agents pour deux modes d'emploi. On a d'abord adapté sur deux bouteilles de méthoxyflurane, d'enflurane et d'halothane le dispositif approprié et la perte de poids de chacun des contenants mesurée sur une période de six semaines. La bouteille étiquettée 1 de chaque agent n'a pas été agitée pendant la pesée; la bouteille étiquettée 2 a été inclinée pour imiter le remplissage d'un vaporisateur. La perte du poids pour la période de six semaines a été de 2.76 pour cent, 3.15 pour cent respectivement pour les bouteilles 1 et 2 contenant l'halothane, 2.22 pour cent et 2.43 pour cent pour 
l'enflurane et 0.58 pour cent et 0.96 pour cent pour le methoxyflurane. Deuxièmement, on a mesuré la pollution a l'aide d'un analyseur à infra-rouges pour les bouteilles 1 et 2 d'halothane et pour un troisième flacon du même agent sur lequel on a replacé le bouchon après chaque remplissage du vaporisateur. La fuite de vapeur n'a pas pu être détectée dans la bouteille 1 , a été de 25 à 30 p.p.m. pour la bouteille 2 et entre 350 et 400 p.p.m. pour la bouteille 3. Ainsi bien que la conception de ces dispositifs puisse permettre une perte d'agent volatil, cette perte ne représente une pollution potentielle que lorsque le dispositif est remplacé par le bouchon entre les usages. De là, on conclut que ces dispositifs de remplissage devraient être laissés sur les flacons pour diminuer la pollution dans les salles d'opération. 